\title{
Factors Affecting Unemployment Duration of the Science and Arts Stream University Graduates in Sri Lanka
}

\author{
G. K. D. L. L. Gunarathne*, C. L. Jayasinghe \\ Department of Statistics, Faculty of Applied Sciences, University of Sri Jayewardenepura, Gangodawila, \\ Nugegoda, Sri Lanka. \\ *Corresponding author email: lakma0423@gmail.com
}

Received: 14 November 2020 / Revised: 19 March 2021 / Accepted: 26 March 2021 / Published: 03 April 2021

\begin{abstract}
Sri Lanka has a significant youth unemployment problem. In the recent years, a more serious problem is graduate unemployment. Therefore, Sri Lanka needs to develop appropriate policies to decrease the duration of unemployment. In this regard, research is required to determine the factors that affect unemployment duration of graduates in order to provide the policy makers with solid foundations for their decision-making processes. Globally several studies have investigated unemployment duration of graduates. Up to date, no study has been done in Sri Lanka that thoroughly investigates the unemployment duration of graduates in Sri Lanka. Thus, the main aim of this research is to identify the factors that affect the duration of unemployment in the Science and Arts stream graduates in Sri Lanka. A survival analysis was conducted to determine how the considered factors affect the duration of unemployment among the Science stream graduates. Due to the nature of the information gathered in relation to the unemployment duration of the Arts stream graduates, an ordinal logistic regression was applied to identify the significant variables of unemployment duration of the Arts stream graduates among the variables considered. The findings of this study show that the Semi Parametric Cox Proportional model is appropriate to determine the relationship between graduates' time taken to obtain the first job and explanatory variables. According to the analysis, the gender, the type of the degree, the job category (private or government sector jobs) and the results of the GCE Advanced Level General English subject have a significant impact on unemployment duration of Science stream graduates. For the Arts stream graduates, the family income, the professional courses followed by graduates during their academic years at the university and the participation in extra-curricular activities while in the university were found to be significant.
\end{abstract}

Keywords: Graduate unemployment, Survival analysis, Ordinal logistic regression model

\section{Introduction}

According to the definition of the International Labor Organization, unemployment occurs when people are without jobs and they have actively looked for work within the past four weeks of such a search. Rapid population growth, economic inflation, economic recession, changing technology, the demand for highly skilled labor, global competition and illiteracy are some of the main causes for unemployment. Dickens and Lang (1995) stated that, several factors impact unemployment in Sri Lanka. These reasons are still valid in Sri Lanka. The first reason they mentioned was "asymmetric capabilities". In other words, there's an asymmetric relation between the requirements of the labour market and the qualifications the candidates should fulfill when applying for jobs in Sri Lanka. Secondly "awaiting for queue" which means that Sri Lankans prefer private sector jobs more than government sector jobs, hence they wait for these to appear in the job market. Thirdly, due to the fact that compared to labour force development, "economic growth has not rapidly increase in Sri Lanka". Furthermore, the generation of jobs in Sri Lanka is limited to the 
Factors Affecting Unemployment Duration of the Science and Arts Stream University Graduates in Sri Lanka

private sector due to the impact of labor law. Jayathilake (2020) stated that a higher level of youth unemployment for a longer period brings a robust influence on the GDP per capita in Sri Lanka. Therefore, Jayathilake (2020) recommend that the government should invest more in education to advance the employability skills of the youth.

The unemployment rate is a measure of the diffusion of unemployment and it is calculated as a percentage by dividing the number of unemployed persons by all the individuals in the labor force (Unemployment Rate Definition, 2020). Sri Lanka's unemployment rate for the first quarter of 2020 is 5.7 percent according to the Labor Force Survey conducted by the Department of Census and Statistics in the first quarter of 2020. It was also concluded that the unemployment among females in all the age groups is higher than that of men who contributed to the overall unemployment in the country. There are four dimensions which can arise in unemployment, namely, educated unemployment, self-unemployment, female unemployment and youth unemployment.

Unemployment has been talked about a lot in the country recently. It is highly ironical how even with university degrees, graduates have to stay at home looking for jobs for months. The duration of unemployment that is the length of time spent being unemployed from graduation, gives an indication as to how difficult it is for an out of work person to re-enter the world of employment or how difficult it is to find the first job.

Unemployment duration is particularly longer among the more educated. As workers with higher education hope high reservation wages by more than the employers are willing to pay. According to El Khouli (2021) the probability of falling into the unemployment problem was higher for those who obtained a higher education level due to the failure of the higher education systems to fulfil the requirements of labor markets. However, Dickens and Lang (1995) have stated that by controlling for gender, sector and age, the positive relation between education and unemployment disappears for urban youth and is significantly weakened for rural youth. Controlling for age, there are higher unemployment rates for educated youth because they have spent more time for their education.

University education is the main mode of higher education in Sri Lanka. As presented in Table 1, people with the highest educational qualification have the highest unemployment rate, in other words they have to wait for a long time to get a job. There are job opportunities for graduates in the private sector mainly for Science, Engineering, Management and Commerce graduates but lesser opportunities exist for Social Sciences and Humanities graduates (Ariyawansa, 2008).

Table 1: Number of Unemployed and Unemployment Rate by Level of Education and Gender, 2020 First Quarter in Sri Lanka (Department of Census and Statistics, Labour force survey quarterly report, 2020)

\begin{tabular}{|c|c|c|c|c|}
\hline \multirow{3}{*}{$\begin{array}{l}\text { Level of } \\
\text { Education }\end{array}$} & \multirow{3}{*}{$\begin{array}{l}\text { Number of } \\
\text { Unemployed } \\
\text { Persons }\end{array}$} & \multicolumn{3}{|c|}{ Unemployment Rate (\%) } \\
\hline & & \multirow[b]{2}{*}{ Sri Lanka } & \multicolumn{2}{|l|}{ Gender } \\
\hline & & & Male & Female \\
\hline Below GCE O/L & 170784 & 3.4 & 2.7 & 5.4 \\
\hline GCE O/L & 108584 & 7.2 & 5.2 & 11.1 \\
\hline GCE A/L and above & 203804 & 10.1 & 5.5 & 14.7 \\
\hline
\end{tabular}

In Sri Lanka there are no sufficient jobs for highly educated people (Ariyawansa, 2008). Most graduates do not have professional qualifications compared to educational qualifications. Professional qualifications additional to education qualifications decrease the unemployment duration (Dissanayake et al., 2010). Today, English Medium Instruction (EMI) over job prospects plays a major role in students' academic verdicts. Altay (2020) Conducted a survey to find out the implications of EMI education for graduates' employment status in Turkey. This study concluded that the duration of seeking a job after graduation is lesser for full EMI graduates than partial EMI graduates. Additionally, Weerasiri and Samaraweera (2021) 
Gunarathne \& Jayasinghe, Adv. J Social Sci.; Vol. 8, Issue 1, pp: 96-120, 2021

concluded that a skills mismatch (including language and digital literacy) and a geographical mismatch influence youth unemployment in Sri Lanka.

Most graduates use social networks as the most prominent method for a job search. Due to the job searcher's perceived usefulness and the perceived ease of use influence, graduates' intentions to use erecruitment and perceived trust has no impact on their intention of using e-recruitment in Sri Lanka (Ekanayaka \& Gamage, 2019). However, certain numbers of graduates still believe in conventional job search methods such as sitting for government recruitment exams and newspaper advertisements. Academic factors such as the university, degree type (e.g. B.Sc. (Honours) degree, B.Sc. (General) degree), the year of graduation, the language medium that the degree was studied at the university, the class of degree and whether it is an honours or general subject stream also help to determine the employability of the graduates (Dissanayake et al., 2010). In addition, personal factors such as age, gender, residence district, district where the General Certificate of Education Advanced Level examination was sat for, postgraduate qualifications, professional qualifications and other (unclassified) qualifications also relate to the career outcomes of the graduates. All parental factors considered including parent's current job status, employed sector and industry, parent's educational level also have been found to have high relationships to the graduates' employability. In addition, the factors that are related to the graduates' previous employment behavior, employment duration, sector and industry, permanent/ temporary status, full/part-time status and reason for quitting the previous jobs also relate with graduates current economic activity.

Unemployment can have a negative impact on both the unemployed individuals and society. At an individual level, mental stress, the loss of self-esteem and poverty can occur especially if unemployed for a longer period. At a social level, civil unrest and increment of crime rates can occur as major drawbacks of unemployment. Furthermore, Cockshott et al. (2021) investigated the experiences of unemployed UK university graduates with mental health issues by using Interpretative Phenomenological Analysis. The loss of expectation and disorientation, a sense of waste and failure because of unemployment, stigma and shame were major issues that affected the mentality of unemployed graduates in this study and Cockshott et al. (2021) suggested to have counselling services in universities that can better manage the transition to the employment of graduates. In addition to this, Khezri et al. (2020) claimed that, unemployed graduates' became anti-social due to the influence of unemployment and it is considered a threat to social and political development.

Most studies carried out to measure the unemployment duration of graduates or the time to obtain first job after graduation have used logistic models, regression models, descriptive analysis, empirical models and economic models (e.g. Dickens and Lang (1995) and Lam et al. (2007)). Recently, some researchers have employed models to identify the determinants of the unemployment duration by using survival analysis techniques (e.g. Babucea and Danacica (2007), Ciuca and Matei (2010) and Gabriel et al. (2017)). The main aim of this paper is to identify the factors that affect unemployment duration of the Science and Arts stream graduates using advanced statistical methods. To investigate the duration of unemployment of Science graduates, survival analysis concepts were used and hence to identify the factors affecting the unemployment duration of Science stream graduates the Cox PH model was applied. Due to the nature of data available related to the Arts stream graduates, an ordinal logistic regression model was applied to identify the factors affecting the unemployment duration of Arts stream graduates.

In Section 2 we provide a thorough review of the relevant literature. The methodology used in data collection, cleaning, and analysis is described in Section 3 while Section 4 is reserved to discuss the results related to the descriptive analysis of the dataset as well as the composition of the data and the conclusions derived through model fitting. Section 5 includes a discussion of the results, conclusions obtained as well as the limitations of the study and some recommendations for further work, related to the topic.

\section{Literature Review}

Unemployment is a broadly discussed matter that considers a variety of objects such as unemployment duration, determinants of unemployment duration and the role of education for the duration of 
unemployment. Recently, some researchers have employed models to identify the determinants of unemployment duration. Foley (1997) used a competing-risk, discrete-time duration model to identify significant factors which affect the length of unemployment spells in Russia. Foley (1997) concluded that better educated individuals do not appear to find jobs more quickly than the less educated.

Babucea and Danacica (2007) presented the results of the international project "the role of education for the duration of unemployment for Gori Country in Romania" conducted by the ASO research group. Babucea and Danacica (2007) used the Kaplan Meier method and the Cox proportional hazard model to find the education level influence on the duration of unemployment in Gori country. They considered five education levels, without graduated school, unfinished secondary school, vocational school (maximum number of 10 years of study), high school (12 to 13 years of study), foremen school and post high school (14 years of study), and university (15 to 17 years of study). Babucea and Danacica (2007) concluded that persons with a university education level remain unemployed for 5 months on average and also persons without education and persons with maximum 10 years of education remain unemployed for 13 months and 9 months respectively.

Boudarbat (2008) developed and estimated a model of endogenous choice of employment sector in an inter-temporal context for a dual labor market to provide a rational explanation for the remarkably high unemployment rate affecting university graduates in the Morocco labor market. Boudarbat (2008) concluded that educated workers are directly encouraged to seek employment in the private sector and workers with postsecondary education should focus on the needs of the labor market. Boudarbat (2008) suggested that the government should improve employment opportunities and working conditions in the private sector.

A survival analysis has been carried out by Ciuca and Matei (2010) to estimate the unemployment duration in Romania and to find some factors that influence the probability of leaving unemployment. They used the Kaplan-Meier method (Product Limit Estimator) to estimate the survival function. To compare survival curves Ciuca and Matei (2010) used the Log Rank Test. They used the Cox Proportional Hazard model to analyze survival data. They considered unemployment duration, age, gender, education level and country as variables. Under education level they considered four levels as elementary school, vocational education, high school and higher education. Ciuca and Matei (2010) concluded that the unemployed people with higher education are not advantaged on the labour market and there are no significant differences between women and men concerning the unemployment duration.

More recently, Gabriel et al. (2017) also used survival techniques to estimate the unemployment duration in Botosani. They studied the impact of individual characteristics such as gender, age, place of residence (rural or urban), unemployment benefits etc. on the length of unemployment spells. Gabriel et al. (2017) used the Cox Regression model to measure the effects of gender, age, residential environment, etc. on the hazard rate of leaving unemployment and used the Kaplan-Meier estimator to compare survival probabilities among different categories of unemployed persons. By using Kaplan-Meier estimates Gabriel et al. (2017) concluded that there's a significant difference between the unemployed beneficiaries and the unemployed persons that are not receiving any benefits, between the graduates who recently graduated and the persons without any income and also between the unemployed belonging to different age groups.

Getie Ayaneh et al. (2020) carried a study to predict the waiting time for first employment and to determine the factors affecting the unemployment duration of graduates by using the 2018 graduate tracer survey data from Debre Markos University. This study used the Cox PH and log-logistic parametric models and the best fitting model was found through comparing Akaikies Information Criterion (AIC). The median waiting time until the first job of graduates was found as 15 months after graduation and that was by $50 \%$ of graduates. The results of Getie Ayaneh et al. (2020) indicated that gender, cumulative grade point average (CGPA), age at graduation, residence, the field of study and faculty significantly affected the duration of unemployment.

According to Dickens and Lang (1995) Sri Lanka has a significant chronic unemployment problem. The ILO report 2013, argued that Sri Lanka's serious unemployment problem can be attributed to the mismatch 
between workers' aspirations and the available jobs which resulted from Sri Lanka's progressive educational policies which by giving wide access to education, raise unrealistic vocational expectations. Dickens and Lang (1995) conducted an analysis to cast the argument. By using estimated distribution of unemployment duration Dickens and Lang (1995) concluded that unemployment duration is very long for all education groups except for those with no schooling. Jayasingha and Suraweera (2020) used the linear regression model and correlation analysis to observe the factors affecting the graduates' employability in Sri Lanka. Results of Jayasingha and Suraweera (2020) indicated that gender, professional qualification, English proficiency, training and experience, and soft skills significantly impact graduate employability while the technological skills partially influence and the degree type did not reflect a significant impact on graduate employability. Further, Wimalarathna et al. (2020) conducted research to figure out the causes of unemployment among the educated youth in Sri Lanka based on the 2016 Department of Census and Statistics survey data. Wimalarathna et al. (2020) analyzed data by using a probit regression model and the results concluded that the living area had a positive influence on educated youth unemployment. Nevertheless, the education level, gender and vocational training displayed a significant negative impact on the unemployed educated youth in Sri Lanka.

Although around the world several studies have been conducted on the duration of unemployment so far, no study has been conducted in Sri Lanka to assess the unemployment duration of graduates in Sri Lanka using survival analysis methods.

\section{Methodology and Data}

This section aims to outline and discuss in depth, the methods used in the preliminary and advanced analysis of data. This also includes an overview of the methodology of data collection as well as the preparation of data for analysis.

\subsection{Data collection and preparation for analysis}

The research design for this study was a retrospective survival study design. Both primary and secondary data were used in this study. The sample of data relates to graduates who registered as undergraduates in the Faculty of Applied Sciences, University of Sri Jayewardenepura, Sri Lanka and was obtained from the Academic, Student Affairs Branch university database which contains details related to Science stream graduates. A questionnaire was used to collect primary data. Details of 185 Science graduates were collected, upon excluding graduates who are doing higher studies abroad. Graduates' information related to gender, age of graduates when they found their first job, the marital status at the time of the first job, the overall GPA, the type of degree, job search strategies that were used to find the first job, whether they had completed professional course(s) or not, results obtained for the G.C.E. advanced level General English subject, the name of the school that graduates have completed their secondary education, participation in extra-curricular activities while at the university, the main goal after graduation, whether they have received university colours or not, time to first job (in days), job type, and the family income of graduates at the time they got their first job were collected by telephone interview. Information of 110 graduates of the Faculty of Humanities and Social Sciences, University of Sri Jayewardenepura were obtained in an existing research database used for analysis with the owner's permission (Table $2 \&$ Table 3 ). 
Factors Affecting Unemployment Duration of the Science and Arts Stream University Graduates in Sri Lanka

Table 2: Variables and Operationalization of Variables (data related to Science stream graduates)

\begin{tabular}{|c|c|c|}
\hline Variable & Operationalization of variable & Measurement \\
\hline Age & $\begin{array}{l}\text { Age of a graduate at the time of getting the } \\
\text { first job }\end{array}$ & Years \\
\hline Gender & Gender of a graduate & "Male" or "Female" \\
\hline Marital Status & $\begin{array}{l}\text { Marital status of a graduate at time of getting } \\
\text { the first job }\end{array}$ & "Single" or "Married" \\
\hline Stream & Degree category & "Bio science" or "Physical science" \\
\hline GPA & Overall GPA of a graduate & GPA score \\
\hline Education Level & Education level of a graduate i.e. degree type & $\begin{array}{l}\text { "B.Sc. (Honours)", "B.Sc. (General)", } \\
\text { "B.Sc. (Honours) in Applied sciences" }\end{array}$ \\
\hline $\begin{array}{l}\text { Professional } \\
\text { courses }\end{array}$ & $\begin{array}{l}\text { Professional courses done by a graduate by } \\
\text { the time he/she got his } \backslash \text { her first job }\end{array}$ & $\begin{array}{l}\text { "Business Management", "IT", } \\
\text { "Other", "No" }\end{array}$ \\
\hline Workshop & $\begin{array}{l}\text { Whether the graduate took part in any } \\
\text { workshops that are designed to improve job } \\
\text { prospects }\end{array}$ & "Yes" or "No" \\
\hline School Region & Region of High school & "Rural", "Urban" \\
\hline $\begin{array}{l}\text { Advanced Level } \\
\text { English }\end{array}$ & $\begin{array}{l}\text { Result obtained for GCE Advanced Level } \\
\text { English }\end{array}$ & "A", "B”, “C”, “S”, "F” \\
\hline University colours & $\begin{array}{l}\text { Whether a graduate received university } \\
\text { colours or not }\end{array}$ & "Yes", "No" \\
\hline $\begin{array}{l}\text { Extra-curricular } \\
\text { activities }\end{array}$ & $\begin{array}{l}\text { Extra-curricular activities done by a graduate } \\
\text { while at the university }\end{array}$ & $\begin{array}{l}\text { "Clubs", "Organizing } \quad \text { events", } \\
\text { "Sports", "No" }\end{array}$ \\
\hline Goal & $\begin{array}{l}\text { Main goals of a graduate after completing the } \\
\text { degree }\end{array}$ & $\begin{array}{l}\text { "Find a job related to the field of } \\
\text { study", "Find any job", "Doing higher } \\
\text { studies", "Other" }\end{array}$ \\
\hline Time to first job & $\begin{array}{l}\text { Time that a graduate took to get the first job } \\
\text { after graduation }\end{array}$ & Number of Days \\
\hline Job Type & Type of the first job & $\begin{array}{l}\text { "Government", "Private", "Semi- } \\
\text { Government", "Self-employed" }\end{array}$ \\
\hline $\begin{array}{l}\text { Job search } \\
\text { strategy }\end{array}$ & $\begin{array}{l}\text { Methods used by a graduate to find his/her } \\
\text { first job }\end{array}$ & $\begin{array}{l}\text { "Asking relatives or friends", } \\
\text { "'Responding job advertisement", } \\
\text { "Taking part in an exam", "Contacting } \\
\text { employers directly", "Other" }\end{array}$ \\
\hline Family Income & $\begin{array}{l}\text { Family income of a graduate per month at the } \\
\text { time he/she found his/her first job }\end{array}$ & $\begin{array}{l}\text { "Less than Rs.20 000", "Rs.20 } 000 \text { - } \\
\text { Rs.30 000", "Rs.30 000 - Rs.40 000", } \\
\text { "More than Rs.40 000" }\end{array}$ \\
\hline $\begin{array}{l}\text { Employment } \\
\text { services }\end{array}$ & $\begin{array}{l}\text { Whether the graduate was registered as a } \\
\text { jobseeker with an employment service }\end{array}$ & "Yes", "No" \\
\hline $\begin{array}{l}\text { Job related to field } \\
\text { of study }\end{array}$ & $\begin{array}{l}\text { Whether the first job is related to the field } \\
\text { studied in the university }\end{array}$ & "Yes", "No" \\
\hline
\end{tabular}


Gunarathne \& Jayasinghe, Adv. J Social Sci.; Vol. 8, Issue 1, pp: 96-120, 2021

Table 3: Variables and Operationalization of Variables (data related to Arts stream graduates)

\begin{tabular}{|c|c|c|}
\hline Variable & Operationalization of variable & Measurement \\
\hline Gender & Gender of graduates & "Male" or "Female" \\
\hline Family Income & $\begin{array}{l}\text { Family income of a graduate per month at the } \\
\text { time he/she found his/her first job }\end{array}$ & $\begin{array}{l}\text { "Less than Rs.20 000", "Rs.20 } 000 \text { - } \\
\text { Rs.30 000", "Rs.30 000 - Rs.40 000", } \\
\text { "More than Rs.40 000" }\end{array}$ \\
\hline School Region & Region of High school & "Rural", "Urban" \\
\hline $\begin{array}{l}\text { Advanced Level } \\
\text { English }\end{array}$ & $\begin{array}{l}\text { Result obtained for GCE Advanced Level } \\
\text { English }\end{array}$ & "A", "B”, “C", "S", “F” \\
\hline $\begin{array}{l}\text { Extra-curricular } \\
\text { activities }\end{array}$ & $\begin{array}{l}\text { Extra-curricular activities done by a graduate } \\
\text { while at the university }\end{array}$ & $\begin{array}{l}\text { "Clubs", "Organizing events", } \\
\text { "Sports", "No" }\end{array}$ \\
\hline $\begin{array}{l}\text { Professional } \\
\text { courses }\end{array}$ & $\begin{array}{l}\text { Professional courses done by a graduate by } \\
\text { the time he/she got his/her first job }\end{array}$ & $\begin{array}{l}\text { "Business Management", "IT", } \\
\text { "Other", "No" }\end{array}$ \\
\hline Workshop & $\begin{array}{l}\text { Whether the graduate took part in any } \\
\text { workshops that are designed to improve job } \\
\text { prospects }\end{array}$ & "Yes" or "No" \\
\hline $\begin{array}{l}\text { Employment } \\
\text { services }\end{array}$ & $\begin{array}{l}\text { Whether the graduate was registered as a } \\
\text { jobseeker with an employment service }\end{array}$ & "Yes", "No" \\
\hline $\begin{array}{l}\text { Job search } \\
\text { strategy }\end{array}$ & $\begin{array}{l}\text { Methods used by a graduate to find his/her } \\
\text { first job }\end{array}$ & $\begin{array}{l}\text { "Asking relatives or friends", } \\
\text { "'Responding job advertisement", } \\
\text { "Taking part in an exam", } \\
\text { "Contacting employers directly", } \\
\text { "Other" }\end{array}$ \\
\hline Time to first job & $\begin{array}{l}\text { Time that a graduate took to get the first job } \\
\text { after graduation }\end{array}$ & $\begin{array}{l}\text { "Just passes out", "Within one year", } \\
\text { "Between one to two years", "Between } \\
\text { two to three years" }\end{array}$ \\
\hline
\end{tabular}

\subsection{Descriptive Analysis of the data}

Before conducting an analysis using advanced statistical methods a thorough descriptive study of data related to graduates who completed their degree in the Science stream and the Arts stream were conducted separately to investigate the composition of the samples we are dealing with. As a result, we were also able to identify the potential factors that may be related with their time to obtain the first job and they were considered in the advanced analysis. 


\subsection{Using Survival Analysis to investigate unemployment duration data}

The core of survival analysis is time. Hence, survival analysis is the best suited for modeling and analyzing the duration of events such as unemployment duration (Ciuca, 2010). Applying standard techniques such as linear regression to data generated under the "failure time process" may cause severe problems such as bias and the inadequacy in information.

Survival data have some notable specifications which make them incompatible with traditional multiple linear regression techniques such as the Ordinary Least Square. The first specification is related to censored data in duration models which the Ordinary Least Square method is not able to distinguish between censored and uncensored data. Survival data analysis is based on following the subject over time until the change in state of the subject of interest during the observation time is noticed. If the subject does not experience the change in state during the study period, it will be considered as a right-censored data. Censored data embarks insufficient and incomplete information (Thomas and Reyes, 2014). To illustrate, for instance, right-censored data, suppose that a survey is conducted to observe the length of unemployment of graduates during a selected time period. In some cases, a graduate is not sure when he or she will get a job within that period. The researcher may also loose contact with the graduates and gets incomplete information. In such cases, the researcher knows the date of entry to unemployment, but does not know when they have left the period of unemployment. Further to this, applying regression models to survival data only gives the mean duration, while one may be interested in the effects of variables on the probability of leaving from the unemployment (Thomas and Reyes, 2014). Besides, the Ordinary Least Square may produce negative predicted values, which has no meaning for the unemployment duration. Duration models do not predict negative values for the dependent variables, which show the duration until the occurrence of the event. More precisely, time to state-transition is always positive in survival data while the linear regression can predict negative values.

Let $T$ be the time of occurrence for some event and since $T$ can take any non-negative value, it can be considered as a random variable. Let $t$ be the actual time to event of an individual. Then, $t$ can be considered as a value of the variable $T$. Since $T$ can take different values, it has a probability distribution. Furthermore, suppose that $T$ has a probability distribution with underling probability density function $f(t)$.

Then, the cumulative density function of $T$ is defined as,

$$
F(t)=P(T \leq t)=\int_{0}^{t} f(u) d u .
$$

This refers to the probability that survival time is less than value $t$. Then, the survival function is defined as,

$$
S(t)=P(T>t)=1-F(t)
$$

This represents the probability that, time to obtain first job is greater than or equal to some value $t$. Hence, the survival function represents the probability that graduate unemployed from the effective date of degree to sometime beyond $t$.

The hazard function is commonly used in survival analysis to express the instantaneous risk that an event occurs at time $t$ or hazard of leaving at some time $t$. It is derived from the probability that graduate get the job at time $t$, conditional on the graduate unemployed till time $t$.

Hence the hazard function is defined as,

$$
h(t)=\frac{f(t)}{S(t)}
$$

The hazard function has no upper bound but hazard is always greater than zero. Hazard is an unobservable quantity so we can find only an estimate for it. The true hazard value is always unknown and depends on the individual. Sometimes hazard can be interpreted as a rate. 
Gunarathne \& Jayasinghe, Adv. J Social Sci.; Vol. 8, Issue 1, pp: 96-120, 2021

In this study, we use the survival analysis technique such as the Kaplan-Meier survival function estimator, the Cox Proportional Hazards model to analyze time to obtain the first job of science stream graduates. Next, we discuss these methods in detail.

\subsection{Kaplan Meier (KM) estimate of the survival function}

The Kaplan-Meier estimate of the survival function is an empirical or non-parametric method of estimating $\mathrm{S}(\mathrm{t})$ from none or right-censored data. It is a popular method of the estimation of the survival function as it requires only very weak assumptions and yet utilizes the information content of both fully observed and right-censored data. The sample proportion of observations with event time is greater than $\mathrm{t}$ is considered as the $\mathrm{KM}$ estimator;

$$
\widehat{S(t)}=\prod_{t_{(r)} \leq t} \frac{(n-r)}{(n-r+1)}
$$

where,

$\mathrm{n}=$ total number of graduates in considered sample,

$t_{(r)} \leq t$ - all uncensored $t_{(r)}$ less than or equal $\mathrm{t}$,

$\mathrm{r}=$ positive integers for which $t_{(r)} \leq t$ and

$t_{(r)}=$ time of event occurrence.

Visually we compare survival curves related to different levels of a certain factor by plotting them on the same graph. We use the Log-rank test to compare two or more survival curves and decide whether there is significant difference between the curves statistically. The results of the Log-rank test were used to determine which variables should be included in the multivariate Cox $\mathrm{PH}$ model with a significance level of 0.05 .

\subsubsection{The Cox Proportional Hazards (PH) model}

The Cox Proportional Hazards model (Cox PH) proposed by Cox and Oakes (1990) is a widely used approach to describe the survival of individuals with respect to the associated covariates under investigation. It describes the relation between the event incidence, through the hazard function and a set of covariates. Since hazard is the instantaneous leaving unemployment rate or the force of leaving, the Cox PH model is defined as,

$$
h(t)=h_{0}(t) \exp \left(\sum_{j=1}^{p} b_{j} x_{j}\right),
$$

where the hazard function $h(t)$ is dependent on a set of $p$ covariates. The size of the respective coefficients $\left(b_{1}, b_{2} \ldots b_{p}\right)$ measures the impact of these covariates. The term $h_{0}(t)$ is known as the baseline hazard, which gives the value of the hazard when all $x_{j}{ }^{\prime} s$ are equal to zero/reference level. In Cox PH model, the survival times are not assumed to follow any statistical distribution. However, it assumed that hazard rate and covariates are in a linear relationship. Hence, it is known as a semi parametric method.

The Cox PH model makes two assumptions when fitting a model. The first one is the Proportional Hazard assumption; that is the hazard of the event in any group is a constant multiple of the hazard in any other. This assumption implies some important characteristics in Proportional Hazard (PH) models. Proportionality assumption is tested using Schoenfeld residuals. Schoenfeld residuals are estimated by subtracting the expected values of the covariates from their corresponding observed ones at each failure time. Therefore, Schoenfeld residuals are not defined for censored data. The second assumption is the linearity assumption; that is, it assumed that the hazard rate is in a linear relationship with the covariates. Nonlinearity, an incorrectly specified functional form in the parametric part of the model, is a potential problem in the Cox regression. Martingale residual is a tool that determines the functional form of the 
covariates. Martingale residuals show the difference between the estimated cumulative hazard and its observed values. A smoothed diagnostic plot of predicted values versus Martingale residuals suggests whether the covariates and their functional forms were properly selected. If the plot is linear then the functional form is accepted. Influential observations largely affect in model fitting. To identify the influential observation, dfbeta residuals are used. The "dfbeta" residual is the approximate change in the coefficients if that observation was dropped, scaled by the standard error for the coefficients.

\subsubsection{Goodness-of-fit measures}

Goodness-of-fit measurements assess the overall fitness of the model. They show how the observed values differ from real data. In ordinary linear regression models, the most popular goodness of fit criteria is $\mathrm{R}^{2}$ which shows the variation in dependent variable with respect to explanatory variables. It is based on the residual sum of squares and results from the decomposition of sums of squares.

In survival models, due to the presence of censored observations, it is a complicated task to define the residuals, and thus $\mathrm{R}^{2}$ may not be an applicable assessment. Thus, proper and convenient measurements for goodness-of-fit in the duration models should be considered. The $\mathrm{R}$ software provides the commands to evaluate the goodness-of-fit graphically using Cox-Snell residuals. It is more appropriate to use the concordance index rather than $\mathrm{R}^{2}$ for assessing the fit. The concordance index $(\mathrm{C})$ measures the predictive ability of the model.

$$
\begin{aligned}
& C>0.5 \text { implies a good predictive ability, } \\
& C=0.5 \text { implies no predictive ability and } \\
& C<0.5 \text { implies poor predictive ability. }
\end{aligned}
$$

\subsection{Ordinal Logistic Regression Model}

Ordinal logistic regression is used when the response variable is categorical with more than one ordinal category. There are some assumptions in ordinal logistic regression. They are, the dependent variable should be measured on an ordinal level, should be one or more independent variables, two or more independent variables should not be highly correlated to each other and the parameters should not be changed for different categories. The ordinal logistic regression model is defined as,

$$
\operatorname{logit}[p(y \leq j \mid \underline{x})]=\beta_{j o}+\underline{\beta}^{T} \underline{x},
$$

where,

$$
\begin{aligned}
& \underline{x}-\text { vector of predictor variables } \\
& \mathrm{j}=1,2 \ldots \mathrm{J}-1, \\
& \mathrm{~J}-\text { number of categories in response variable } \\
& \beta_{j o}-\text { constant associated with the } \mathrm{j}^{\mathrm{th}} \text { distinct response category and } \\
& \underline{\beta}^{T}-\text { vector of coefficients. }
\end{aligned}
$$

In our study, time to obtain the first job of Arts graduates' have been coded as just passed out, within one year, between one to two years and between two to three years. Hence, the ordinal logistic regression model, was used to identify the factors that affect the time taken to find the first job of Arts stream graduates.

\section{Results of the study}

In this section we present and discuss the results of the data analysis conducted. In Sections 4.1 and 4.2, we present the results of the descriptive analysis conducted on data related to the Science and Arts streams graduates' respectively. In Sections 4.3 and 4.4, we discuss the results of the fitted models and identify the factors that affect the durations of unemployment of graduates of the two streams. 


\subsection{Descriptive Analysis of the data related to science stream graduates}

As observed in Table 4 (a) most graduates in the sample of 185 graduates are female. Table 4 (b) shows that most of the graduates in the sample were B.Sc. (General) degree holders. According to Table 4 (c), most B.Sc. (Honours) degree holders of the sample were females and it is approximately 60.42 percent. As in Table 4 (d), a majority of graduates got "C" passes at the Advanced Level General English results and it is approximately 36.22 percent out of the considered sample. A further analysis revealed that, a majority of the graduates who got "B", "C", "S" and "F" passes for Advanced Level General English followed subjects in the physical science stream. Most graduates who got "B" and "F" passes for Advanced Level General English did not consider about the distance from their residence to their work place when they found their first job. Most graduates who got "C" and "F" passes for the Advanced Level General English subject did not consider about the working environment when they found their first job. According to Table 4 (e), out of the graduates who got "F" passes for their Advanced Level English, 78.57 percent were males in the sample. A majority of graduates who got other grades except $F$ were females in the relevant sample.

Table 4: Composition of the data related to science stream graduates

\begin{tabular}{lrr}
\hline Gender & Count & Percent (\%) \\
\hline Female & 104 & 56.22 \\
Male & 81 & 43.78 \\
\hline
\end{tabular}

\begin{tabular}{lrr}
\hline Education Level & Count & Percent (\%) \\
\hline B.Sc. (Honours) & 36 & 19.46 \\
B.Sc. (Honours) in Applied Sciences & 101 & 54.59 \\
B.Sc. (General) & 48 & 25.95 \\
\hline
\end{tabular}

(a)

\begin{tabular}{lrrr}
\hline & $\begin{array}{c}\text { B.Sc. } \\
\text { (Honours) }\end{array}$ & $\begin{array}{c}\text { B.Sc. } \\
\text { (Honours) } \\
\text { in Applied } \\
\text { Sciences }\end{array}$ & $\begin{array}{c}\text { B.Sc. } \\
\text { (General) }\end{array}$ \\
\hline Female & 29 & 25 & 50 \\
Male & 60.42 & 69.44 & 49.50 \\
& 19 & 11 & 51 \\
& 39.58 & 30.56 & 50.50 \\
\hline
\end{tabular}

Column: Education Level

Cell Content: Count

\begin{tabular}{lrrrrr}
\multicolumn{7}{c}{ \% of column } \\
\hline & \multicolumn{1}{c}{ A } & \multicolumn{1}{c}{ B } & \multicolumn{1}{c}{ C } & \multicolumn{1}{l}{ S } & \multicolumn{1}{c}{ } \\
\hline Female & 20 & 28 & 38 & 15 & 3 \\
& 60.61 & 60.87 & 56.72 & 60.00 & 21.43 \\
Male & 13 & 18 & 29 & 10 & 11 \\
& 39.39 & 39.13 & 43.28 & 40.00 & 78.57 \\
\hline
\end{tabular}

Column: G.C.E. A/L Results Cell Content: Count

(e) (b)

\begin{tabular}{lrr}
\hline $\begin{array}{c}\text { A/L English } \\
\text { Results }\end{array}$ & Count & Percent (\%) \\
\hline A & 33 & 17.84 \\
B & 46 & 24.86 \\
C & 67 & 36.22 \\
S & 25 & 13.51 \\
F & 14 & 7.57 \\
\hline
\end{tabular}

(d)

\begin{tabular}{lrr}
\hline & $\begin{array}{c}\text { Job related to } \\
\text { the field studied } \\
\text { at university }\end{array}$ & $\begin{array}{c}\text { Job not } \\
\text { related to the } \\
\text { field studied } \\
\text { at university }\end{array}$ \\
\hline Female & 75 & 29 \\
Male & 59.06 & 50.00 \\
& 52 & 29 \\
\hline
\end{tabular}

(f)

According to Table $4(\mathrm{f})$, most graduates who found their first job that is related to the field they studied in the university were female in the sample. Out of B.Sc. (Honours) degree holders who have completed a professional course(s) in the sample, majority have followed courses related to IT, HR, Quantity surveying, etc. Furthermore, out of the B.Sc. (Honours) in Applied Sciences degree holders, 25 percent have followed courses related to HR, Quantity surveying, etc. Furthermore, out of B.Sc. (General) degree holders, a majority have followed professional courses related to HR, Quantity surveying, etc.

Most of the B.Sc. (Honours) degree holders in the sample got "A" passes for their Advanced Level General English subject. Out of the graduates who got "F" passes for the General English subject in the Advanced Level 78.57 percent were B.Sc. (General) degree holders. Furthermore, most of the graduates who found their first job through self-employment in the considered sample were B.Sc. (General) degree holders. Approximately, 75.86 percent of the graduates in the sample were doing a job that is not related to the field 
Factors Affecting Unemployment Duration of the Science and Arts Stream University Graduates in Sri Lanka

studied in the university were B.Sc. (General) degree holders. A majority of B.Sc. (Honours) degree holders have found a job that is related to the field they studied in the university.

\section{Dotplot of Time to first Job (Days)}

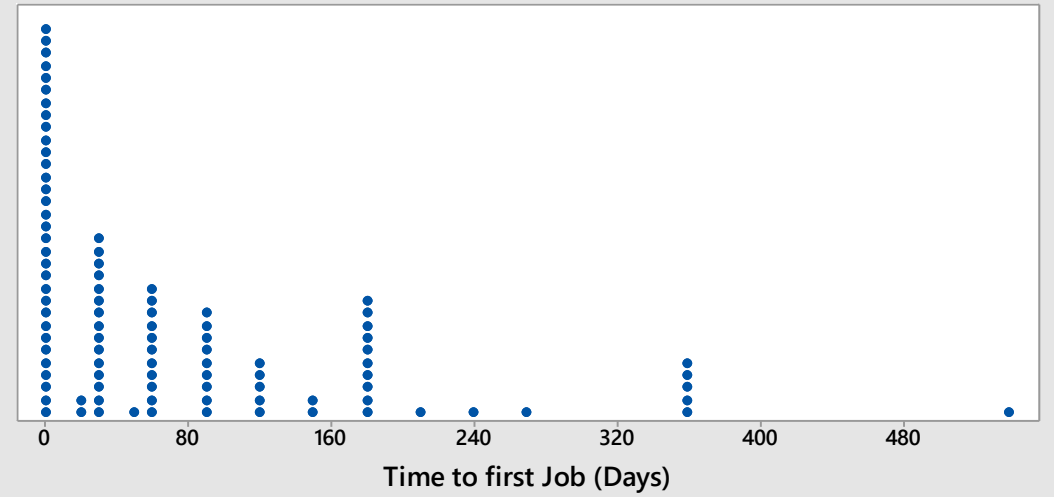

Each symbol represents up to 2 observations.

Figure 1: Distribution of time to first job after graduation

Table 5: Descriptive measures of time to first job after graduation

\begin{tabular}{lrrrrrrrr} 
Variable & N & Mean & St. Dev & Minimum & Q1 & Median & Q3 & Maximum \\
\hline Time to & 185 & 77.94 & 100.06 & 0.00 & 0.00 & 30.00 & 120.00 & 360.00 \\
First job & & & & & & & & \\
\hline
\end{tabular}

According to Figure 1 and Table 5, the time to obtain the first job shows a positively skewed distribution with a median of 30 days. Hence, $50 \%$ of science stream graduates have found their first job within 30 days after graduation. However, by the international project "The Role of Education for the Duration of Unemployment for Gori Country in Romania" Babucea and Danacica (2007) concluded that, persons with university education remain unemployed for 5 months on average.

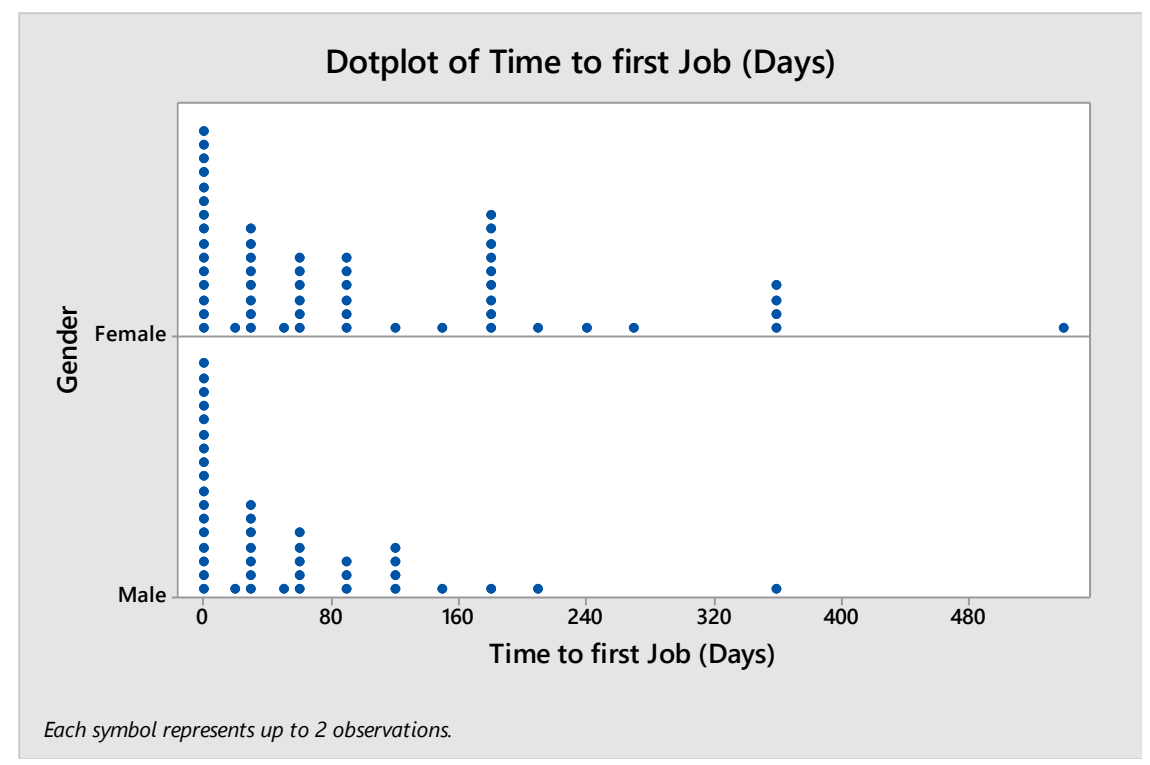

Figure 2: Distribution of time to first job by gender 
Gunarathne \& Jayasinghe, Adv. J Social Sci.; Vol. 8, Issue 1, pp: 96-120, 2021

Table 6: Descriptive measures of time to first job by gender

\begin{tabular}{l|lrrrrrrrr}
\hline Variable & Gender & N & Mean & St. Dev & Min. & Q1 & Median & Q3 & Max. \\
\hline $\begin{array}{l}\text { Time to } \\
\text { first job }\end{array}$ & Female & 104 & 98.4 & 113.7 & 0.0 & 0.0 & 60.0 & 180.0 & 360.0 \\
& Male & 81 & 51.7 & 71.7 & 0.0 & 0.0 & 30.00 & 90.0 & 360.0 \\
\hline
\end{tabular}

As it can be seen from Figure 2 and descriptive measures, the time to obtain the first job for female graduates in the considered sample shows a positively skewed distribution with the median of 60 days. Furthermore, male graduates in the sample also show a positively skewed distribution with a median of 30 days.

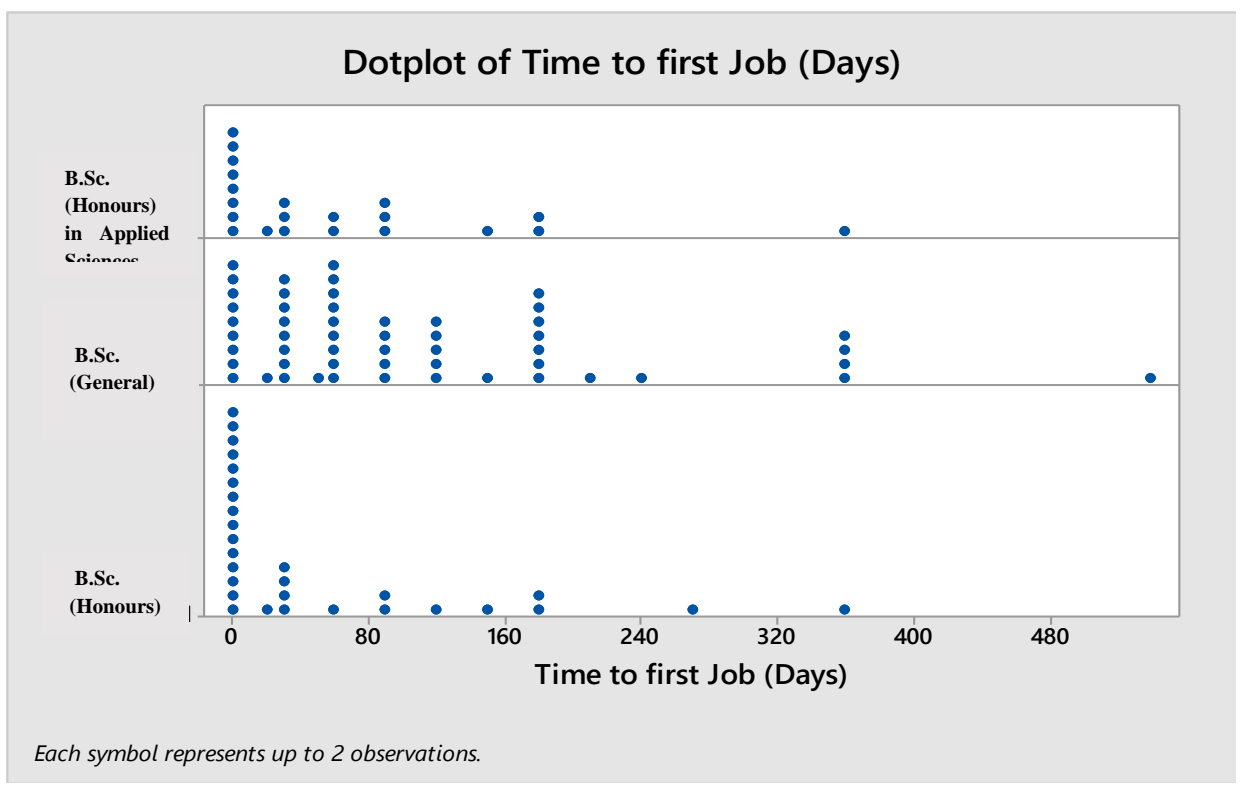

Figure 3: Distribution of time to first job by education level

Table 7: Descriptive measures of time to first job by education level

\begin{tabular}{l|lrrrrrrrr}
\hline Variable & \multicolumn{1}{|c}{ Education level } & N & Mean & St. Dev & Min. & Q1 & Median & Q3 & Max. \\
\hline Time to & B.Sc. (Honours) & 48 & 41.6 & 78.3 & 0.0 & 0.0 & 0.0 & 30.0 & 360.0 \\
First job & $\begin{array}{l}\text { B.Sc. (Honours) in } \\
\text { Applied Sciences }\end{array}$ & 36 & 52.1 & 77.2 & 0.0 & 0.0 & 30.0 & 90.0 & 360.0 \\
& B.Sc. (General) & 101 & 104.4 & 108.9 & 0.0 & 30 & 60.0 & 180 & 360.0 \\
\hline
\end{tabular}

As it can be seen from Figure 3, the time to obtain the first job for B.Sc. (Honours) in Applied Sciences degree holders in the sample shows a positively skewed distribution with a median of 30 days. Furthermore, for B.Sc. (Honours) and B.Sc. (General) degree holders do not show any particular distribution.

According to Figure 4, graduates who got "B" passes and "C" passes for their Advanced Level English in the considered sample show positively skewed distribution with a median of 30 days. Furthermore, graduates who got "A" passes, "S" passes and "F" passes do not show any particular distribution. 


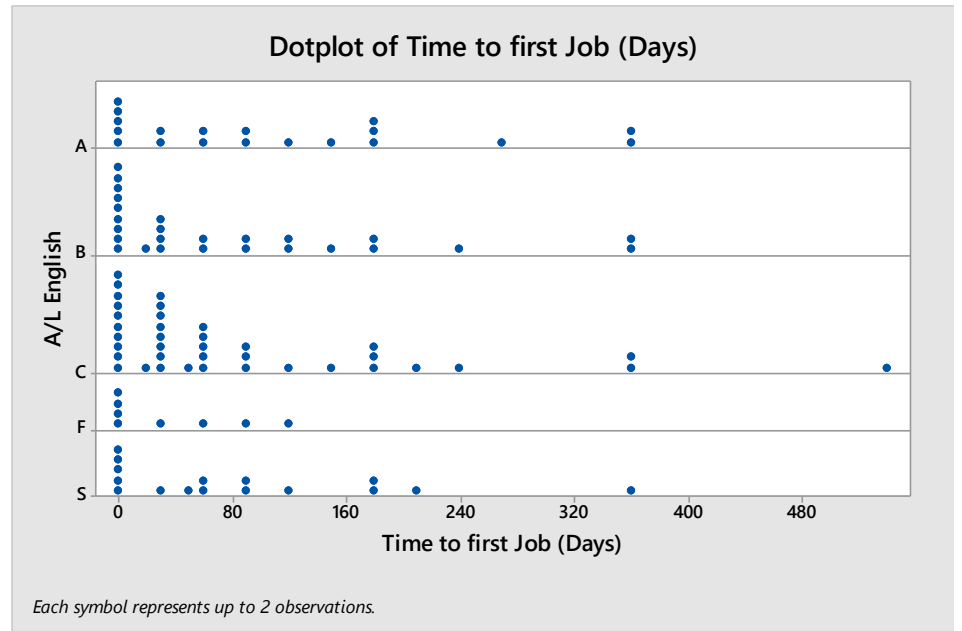

Figure 4: Distribution of time to first job by results obtained for Advanced Level English

Table 8: Descriptive measures of time to first job by results of Advanced Level English

\begin{tabular}{l|lrrrrrrrr}
\hline Variable & Results & N & Mean & St. Dev & Min. & Q1 & Median & Q3 & Max. \\
\hline Time to & A & 33 & 105.5 & 111.0 & 0.0 & 0.0 & 90.0 & 180.0 & 360.0 \\
First job & B & 46 & 69.8 & 99.1 & 0.0 & 0.0 & 30.0 & 120.0 & 360.0 \\
& C & 67 & 77.5 & 104.9 & 0.0 & 0.0 & 30.0 & 90.0 & 360.0 \\
& S & 25 & 82.2 & 91.6 & 0.0 & 0.0 & 60.0 & 150.0 & 360.0 \\
& F & 14 & 34.3 & 42.2 & 0.0 & 0.0 & 15.0 & 67.5 & 120.0 \\
\hline
\end{tabular}

\subsection{Descriptive analysis of data related to arts stream graduates}

According to Table 9 (a), majority of Arts stream graduates in the considered sample were graduates with a Rs.30 000 - Rs.40 000 family income. According to Table 9 (b), a majority of the Arts stream graduates in the sample have not done any extra-curricular activities while studying in the university. Table 9 (c), shows that, most of the graduates in the considered sample were not doing any professional courses and it is approximately $54.5 \%$. As it can be seen from Table 9 (d), a majority of the graduates in the sample were doing jobs in the private sector. According to Table 9 (e), most graduates in the sample have found their first job within one year and it is approximately 75.45 percent. Table 9 (f) shows that, out of the graduates who did Government sector jobs, majority were females and it is approximately 88.89 percent.

According to Table 9 (g), majority of graduates in the sample with less than Rs.20 000 family income has not followed any professional courses and it is approximately 82.76\%. Out of graduates with Rs.30 000 Rs.40 000 family income in the considered sample 77.50 percent found their first job within one year. Furthermore, out of graduates who found their first jobs between one to two years, majority were graduates with less than Rs.20 000 family income. According to Table 9 (h), majority of graduates who were members of clubs such as gavel, CSDS, etc. were female graduates. Majority of graduates who didn't do any extracurricular activities in considered sample have found their first job within one year. Also, most of the graduates who found their jobs just passed out have organized different events such as Speech Master, Aesthetic events, etc. as an extra-curricular activity.

Most graduates who did jobs in government sector were females in the considered sample of arts stream graduates. Out of the male graduates majority have found their first job in the private sector and as a percentage it is 80.85 . Most graduates who followed professional courses in considered sample have found 
Gunarathne \& Jayasinghe, Adv. J Social Sci.; Vol. 8, Issue 1, pp: 96-120, 2021

their first job in private sector. Furthermore, majority of graduates who found their first job through selfemployment have not followed any professional courses and it is approximately $62.5 \%$. Out of 18 graduates who found their first job when just passes out, 61.11 percent of graduates were doing private sector jobs. Most graduates, who found their first job by self-employment, have started their employment within one year. Most of the arts stream graduates in the sample who used a job search strategy to find their first job were doing job in private sector.

Table 9: Composition of the data related to arts stream graduates

\begin{tabular}{lrc}
\hline \multicolumn{1}{c}{ Family Income } & Count & $\begin{array}{c}\text { Percent } \\
(\boldsymbol{\%})\end{array}$ \\
\hline Less than Rs. 20 000 & 29 & 26.36 \\
Rs. 20 000 - Rs. 30000 & 35 & 31.82 \\
Rs. 30 000 - Rs. 40000 & 40 & 36.36 \\
More than Rs. 40 000 & 6 & 5.45 \\
\hline
\end{tabular}

(a)

\begin{tabular}{lcc}
\hline Professional Courses & Count & $\begin{array}{c}\text { Percent } \\
(\mathbf{\%})\end{array}$ \\
\hline Doing Professional Courses & 50 & 45.45 \\
Not doing Professional Courses & 60 & 54.55 \\
\hline
\end{tabular}

(c)

\begin{tabular}{lrr}
\hline Time to First Job (T) & Count & $\begin{array}{c}\text { Percent } \\
(\boldsymbol{\%})\end{array}$ \\
\hline Just passes out & 29 & 26.36 \\
Within one year & 35 & 31.82 \\
Between one to two years & 40 & 36.36 \\
Between two to three years & 6 & 5.45 \\
\hline
\end{tabular}

(e)

\begin{tabular}{lrr}
\hline & $\begin{array}{c}\text { Doing } \\
\text { Professional } \\
\text { Courses }\end{array}$ & $\begin{array}{c}\text { Not Doing } \\
\text { Professional } \\
\text { Courses }\end{array}$ \\
\hline Less than Rs. 20 000 & 5 & 24 \\
Rs. 20 000 - Rs. 30 000 & 17.24 & 82.76 \\
& 19 & 16 \\
Rs. 30 000 - Rs. 40 000 & 54.29 & 45.71 \\
& 22 & 18 \\
More than Rs. 40 000 & 55.00 & 45.00 \\
& 4 & 2 \\
& 66.67 & 33.33 \\
\hline
\end{tabular}

Row: Family Income Cell Content: Count $\%$ of row

\begin{tabular}{lrr}
\hline $\begin{array}{c}\text { Extra-curricular } \\
\text { Activity }\end{array}$ & Count & $\begin{array}{c}\text { Percent } \\
(\boldsymbol{\%})\end{array}$ \\
\hline Clubs & 8 & 7.27 \\
Organizing events & 42 & 38.18 \\
Doing Sports & 6 & 5.45 \\
No & 54 & 49.09 \\
\hline
\end{tabular}

(b)

\begin{tabular}{lrr}
\hline \multicolumn{1}{c}{ Job Type } & Count & $\begin{array}{c}\text { Percent } \\
(\boldsymbol{\%})\end{array}$ \\
\hline Government & 9 & 8.18 \\
Private & 85 & 77.27 \\
Semi - Government & 16 & 14.55 \\
\hline
\end{tabular}

(d)

\begin{tabular}{|c|c|c|c|}
\hline & Gov. & Private & $\begin{array}{l}\text { Semi- } \\
\text { Gov. }\end{array}$ \\
\hline \multirow[t]{2}{*}{ Female } & 8 & 70 & 12 \\
\hline & 88.89 & 82.35 & 75.00 \\
\hline \multirow[t]{2}{*}{ Male } & 1 & 15 & 4 \\
\hline & 11.11 & 17.65 & 25.00 \\
\hline
\end{tabular}

\begin{tabular}{lrr}
\hline & Female & \multicolumn{1}{l}{ Male } \\
\hline Member of clubs & 7 & 1 \\
& 87.50 & 12.50 \\
Organizing events & 33 & 9 \\
& 78.57 & 21.43 \\
Doing sports & 4 & 2 \\
& 66.67 & 33.33 \\
No & 45 & 8 \\
& 85.19 & 14.81 \\
\hline
\end{tabular}

Column: Gender Cell Content: Count \% of row $\quad(\mathrm{h})$

\subsection{Survival analysis conducted on data related to science stream graduates}

Survival curves were fitted using Kaplan-Meier method and the difference between the survival curves were tested using the log rank test. As mentioned in Section 3.3.1 a series of Log-rank tests were conducted to determine which variables should be included in the multivariate Cox PH model with significance level of 0.05. Results of the Log-rank tests conducted revealed that marital status, GPA score (categorized) do not significantly affect unemployment duration of science graduates. Hence, to investigate the joint effect of the remaining variables on graduates' time to obtain first job after graduation a semi - parametric survival method was used. 


\subsubsection{Estimated survival functions $(\mathrm{s}(\mathrm{t}))$ for specific groups of science stream graduates and comparison of time to first job between two or more groups.}

As seen in Figure 5, up to 170 days it decreases rapidly. Then up to 350 days it slows down. It is clear that at 360 days, $\mathrm{KM}$ estimate is 0.0 , and hence the chance of getting a job after graduation takes more than 360 days is not significant for same graduates.

Kaplan-Meier estimate with $95 \%$ confidence bounds

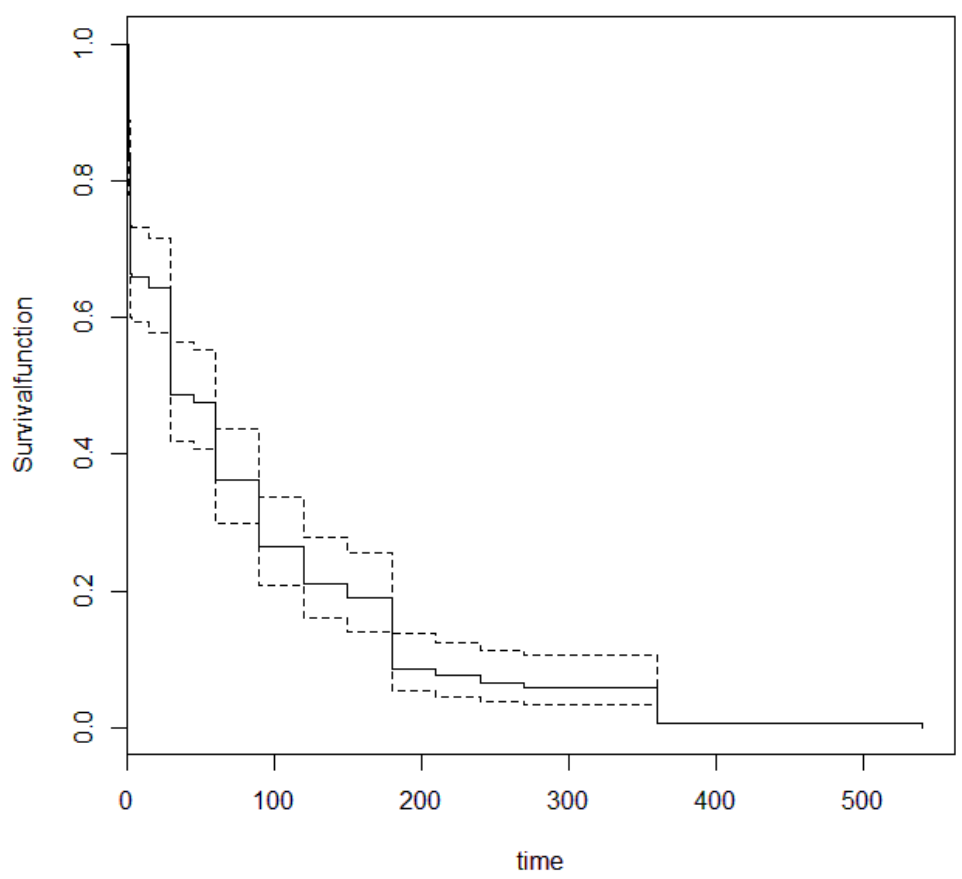

Figure 5: Plot of survival function for science stream graduates in considered sample.

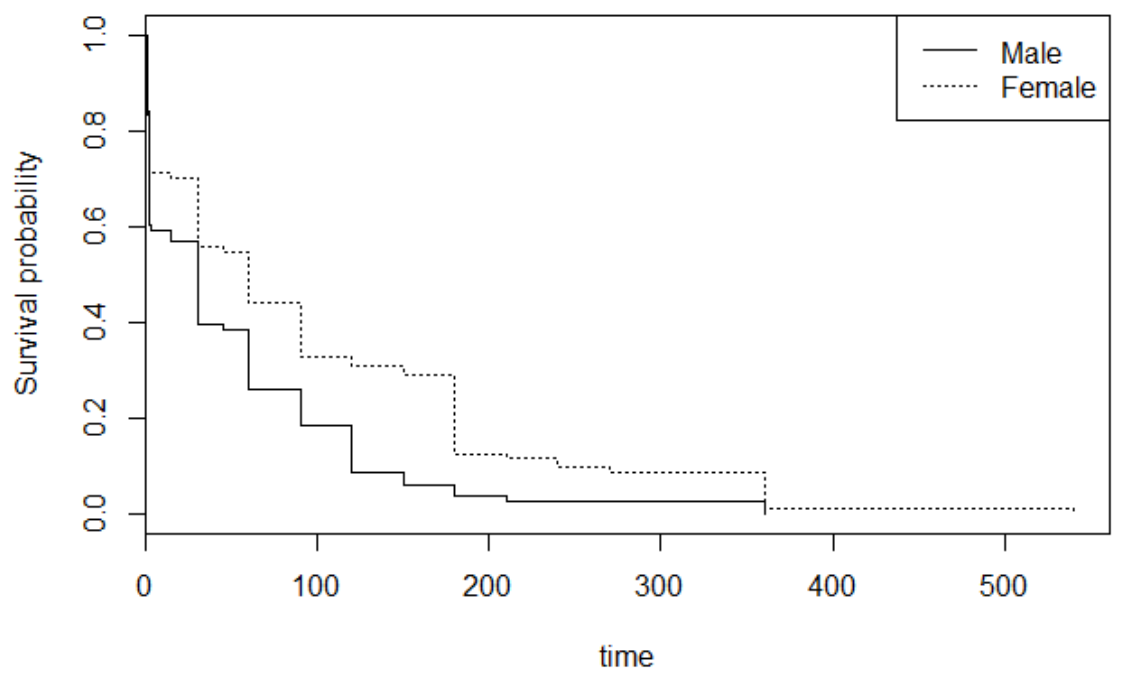

Figure 6: Survival curves: gender of the science stream graduates

As in Figure 6, survival curve belonging to male graduates is lower than female graduates. Around 25 days both curves are close. Both curves are decreasing rapidly until 200 days, after that they remain constant. According to Log Rank Test, the difference we have observed between survival curves in Figure 6 was found to be statistically significant (P value: 0.00957 ). 


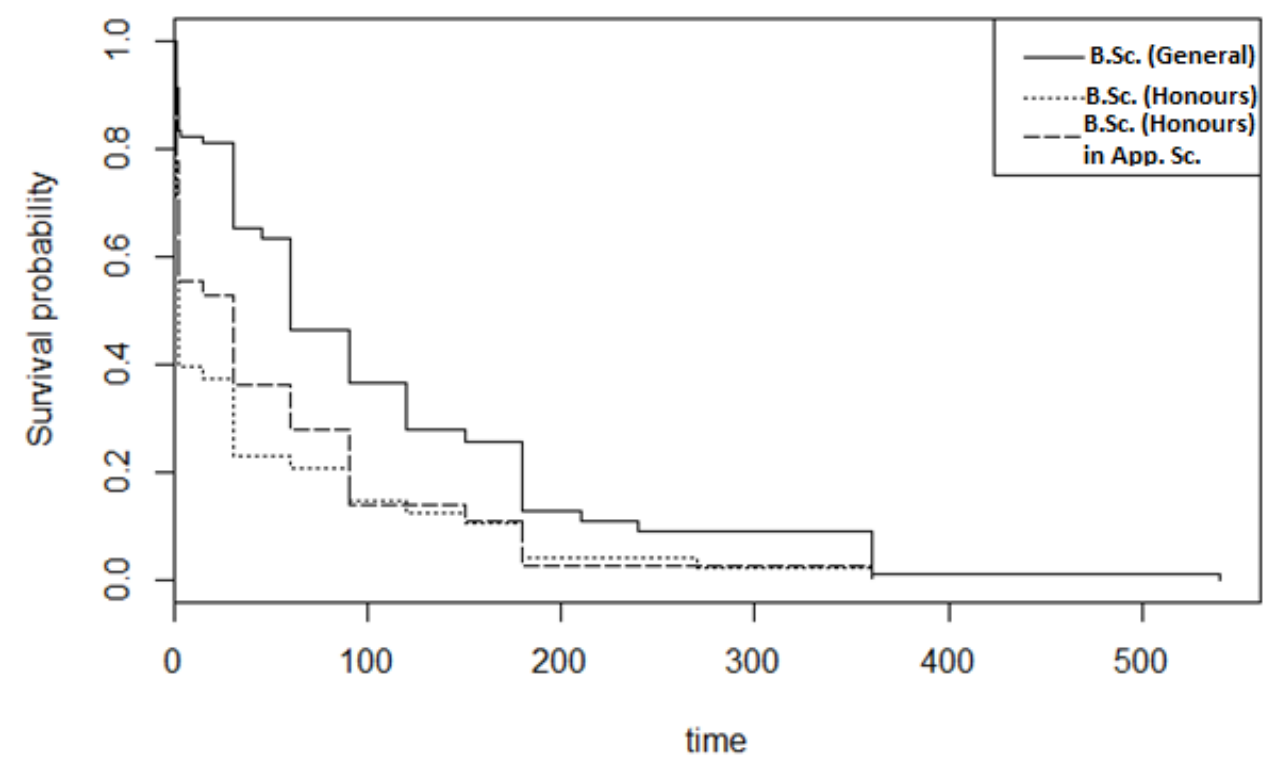

Figure 7: Survival curves: education levels of science stream graduates

As it can be seen from Figure 7, survival curve belonging to B.Sc. (General) degree is higher than other education levels. At 30 days survival curves of B.Sc. (Honours) in Applied Sciences and B.Sc. (Honours) degree are relatively close and after 70 days both curves are approximately same. Since the p value obtained from Log rank Test was less than 0.05 (P value: $2.83 \mathrm{e}^{-05}$ ), it was concluded that there is a significant difference between the survival curves.

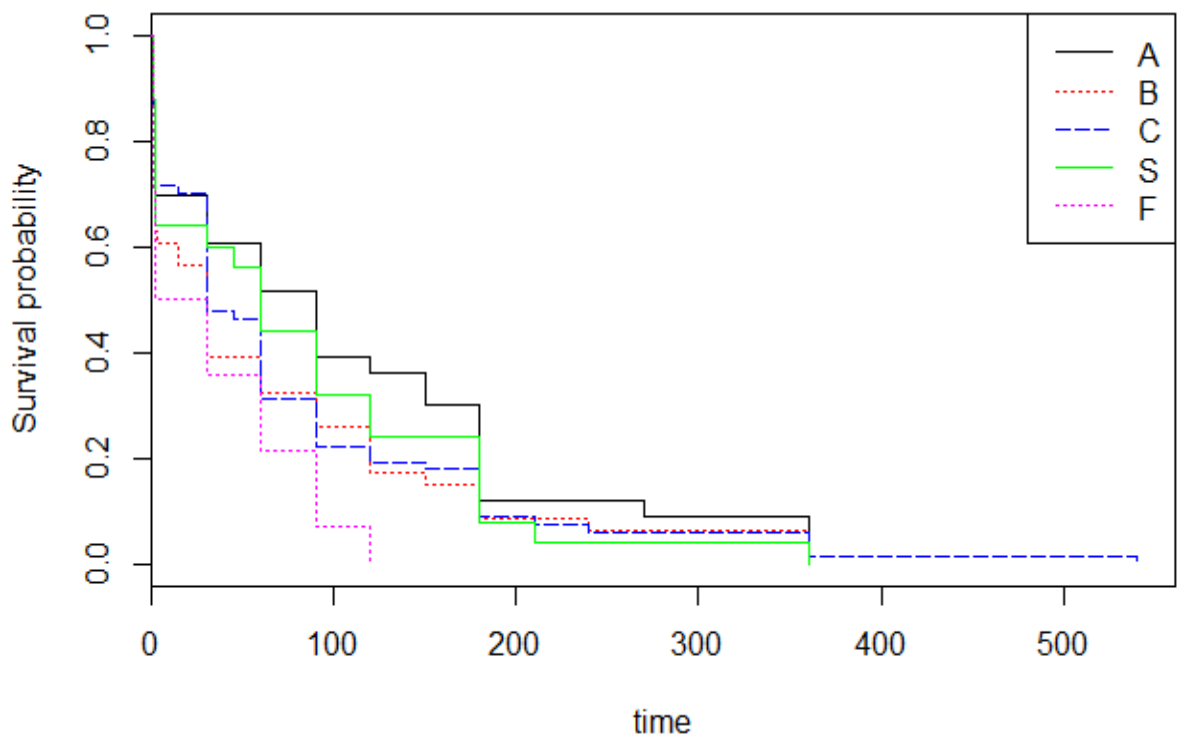

Figure 8: Survival curves: results for Advanced Level English subject

Figure 8 shows that survival curve of graduates who got "A" passes for Advanced Level English is higher than all other curves. At time to obtain first job is between 180 days and 360 days survival curves of graduates who got "B", "C" and "S" passes for Advanced Level English subject are closer each other. According to Log Rank Test, there's no significant difference in survival curves (P value: 0.129). 
Factors Affecting Unemployment Duration of the Science and Arts Stream University Graduates in Sri Lanka

\subsubsection{Identifying factors affecting time to obtain the first job: Cox-Proportional Hazards Model}

Table 10: exp(coefficient) and $P$ values of all the variables in the Cox Proportional Hazards Model for science stream graduates

\begin{tabular}{|c|c|c|c|}
\hline & $\exp$ (Coefficient) & $\operatorname{Pr}(>|z|)$ & \\
\hline Age & 1.169791 & 0.09173 & . \\
\hline \multicolumn{4}{|l|}{ Gender [Male] } \\
\hline Female & 0.597271 & 0.01358 & $*$ \\
\hline \multicolumn{4}{|c|}{ Subject Stream [Physical] } \\
\hline Biology & 0.827099 & 0.33319 & \\
\hline \multicolumn{4}{|c|}{ Education Levels [General] } \\
\hline Special & 3.225353 & $1.37 \mathrm{e}-05$ & * \\
\hline Extended & 2.105527 & 0.00195 & * \\
\hline \multicolumn{4}{|c|}{ Job Search Strategies [Advertisement] } \\
\hline Contacting Directly & 1.019697 & 0.94883 & \\
\hline Exams & 1.829873 & 0.10662 & \\
\hline Friends or relatives & 0.969912 & 0.89281 & \\
\hline Other & 0.857766 & 0.75524 & \\
\hline \multicolumn{4}{|c|}{ Courses [Business Management] } \\
\hline IT & 0.220431 & 0.46134 & \\
\hline Other & 0.962125 & 0.89290 & \\
\hline No & 1.177502 & 0.55206 & \\
\hline \multicolumn{4}{|c|}{ Participation for workshops [Yes] } \\
\hline No & 0.834254 & 0.33494 & \\
\hline \multicolumn{4}{|c|}{ Region of School [Urban] } \\
\hline Rural & 1.011162 & 0.95704 & \\
\hline \multicolumn{4}{|c|}{ Results of A/L English [A] } \\
\hline $\mathrm{B}$ & 1.777919 & 0.03692 & * \\
\hline $\mathrm{C}$ & 1.692874 & 0.04051 & * \\
\hline S & 1.744369 & 0.08967 & . \\
\hline $\mathrm{F}$ & 2.814558 & 0.01130 & * \\
\hline \multicolumn{4}{|c|}{ University Colours [Yes] } \\
\hline No & 0.774972 & 0.42042 & \\
\hline \multicolumn{4}{|c|}{ Extra-curricular Activities [Clubs] } \\
\hline Sports & 1.026832 & 0.93281 & \\
\hline Organizing events & 1.267800 & 0.37016 & \\
\hline No & 0.994031 & 0.98293 & \\
\hline \multicolumn{4}{|c|}{ Goals after graduation [field relate job] } \\
\hline Doing a job & 0.740738 & 0.16450 & \\
\hline Higher Studies & 0.719564 & 0.21428 & \\
\hline Other & 1.106973 & 0.91361 & \\
\hline \multicolumn{4}{|c|}{ Job Type [Government] } \\
\hline Semi-Government & 1.760943 & 0.42726 & \\
\hline Private & 1.877763 & 0.05017 & . \\
\hline Self-employed & 3.106715 & 0.10576 & \\
\hline \multicolumn{4}{|c|}{ Family Income [Rs.20 000 - Rs.30 000] } \\
\hline Rs.30 000 - Rs. 40000 & 0.777692 & 0.56549 & \\
\hline More than Rs.40 000 & 0.789831 & 0.59658 & \\
\hline
\end{tabular}


Gunarathne \& Jayasinghe, Adv. J Social Sci.; Vol. 8, Issue 1, pp: 96-120, 2021

Usage of employment Services [Yes]

No

Relativity of field studied at university to job [Yes]

No

Consideration of salary [Yes]

No

Don't care

Consideration of Working Environment [Yes]

No

Don't care

Consideration of Facilities [Yes]

No

Don't care

Consideration of Leaves and Holidays [Yes]

No

Don't care
1.226823

0.992448

0.97027

1.422917

1.05812

1.033845

0.84314

0.637381

0.97190

1.007544
0.29215

0.97135

0.86207

0.49563

0.65827

0.90178

0.22119

0.14987

0.83625

0.97990

The reference level of each variable mentioned within squared brackets.

Signif. Codes: $0 * * * 0.001 * * 0.01 * 0.05 .0 .11$

Concordance $=0.721(\mathrm{se}=0.031)$

Likelihood ratio test $=54.79$ on $33 \mathrm{df}, \mathrm{p}=0.009967$

Wald test $=52.04$ on $33 \mathrm{df}, \mathrm{p}=0.01874$

Score (logrank) test $=54.89$ on $33 \mathrm{df}, \mathrm{p}=0.00973$

P-values of log likelihood ratio test, Wald test and score test were less than 0.05 suggesting that the model fit the data well. Concordance index of this model is 0.721 . It is greater than 0.5 , so the model has good predictive ability. According to the $\mathrm{p}$-values of the covariates, female graduates, education levels (B.Sc. (Honours) degree and B.Sc. (Honours) in Applied Sciences), results of A/L English ("B" passes, "C" passes and "F" passes) and graduates who doing private sector jobs have a statistically significant effect on the hazard rate or survival probability function. The coefficients of education levels (B.Sc. (Honours) degree and B.Sc. (Honours) in Applied Sciences), results of A/L English ("B" passes, "C" passes and "F" passes) and graduates who doing private sector jobs are positive. Thus, the graduates who did B.Sc. (Honours) degree increases the hazard rate by a factor of 3.23 compared to B.Sc. (General) degree holders. Graduates with B.Sc. (Honours) in Applied Sciences increases the hazard rate by a factor of 2.11 compared to B.Sc. (General) degree holders. Results for A/L English as "B" and "C" passes increase the hazard rate by $78 \%$ and $69 \%$ respectively. According to negative coefficient of graduates' gender, female graduates have a higher chance to being unemployed compared to male graduates. Female graduates in the considered sample decreases the hazard rate by $40 \%$ compared to male graduates.

As a summary we can conclude that female graduates tend to have longer time to obtain the first job compared to male graduates. However, the length of time to obtain first job of graduates who have obtained B.Sc. (Honours) degree and B.Sc. (Honours) in Applied Sciences degree have shorter time to obtain first job than B.Sc. (General) degree holders. Graduates with "B", "C" and "F" passes for Advanced Level English tend to have shorter time to obtain first job than graduates with " $\mathrm{A}$ " pass for Advanced Level English.

The test of nonzero-slope based on the Schoenfeld residuals with the null hypothesis of the "model is adequate" is a useful tool to identify whether the proportional hazard assumption holds. This test gives results for each covariate separately. The p-value of the global test which checks whether the full model meets the proportional hazard assumption was greater than 0.05 , which indicated that there is no evidence 
Factors Affecting Unemployment Duration of the Science and Arts Stream University Graduates in Sri Lanka

for the violation of the proportional hazards assumption. To identify the influential observations, dfbeta residuals were used. By index plots of dfbeta for the covariates in the cox regression suggested that none of the observations are terribly influential individually. Nonlinearity is not an issue for categorical variables, therefore examination was done by using plots of martingale residuals against the numerical variable "Age" only. Martingale plot seems to be uniform and revealed no trend along the values. Hence, non-linearity assumption has not been violated.

\section{Cox Snell Residual plot}

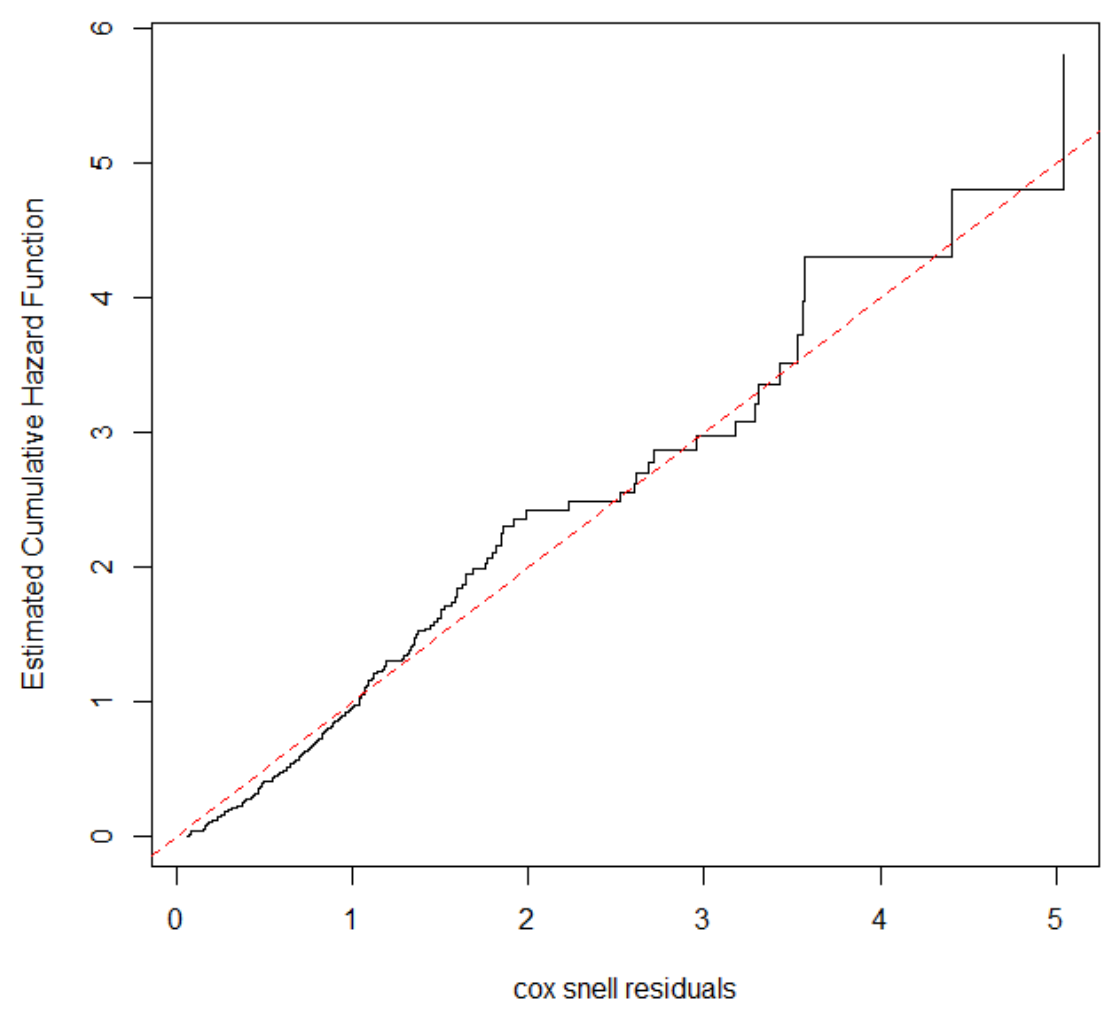

Figure 9: Cox-Snell residual plot from the fitted Cox Proportional Hazards model

Since Cox-Snell residual plot in Figure 9, shows a curve close to a straight line with unit slope and zero intercept, the fitted model is acceptable.

\subsection{Ordinal logistic regression analysis of data related to arts graduates}

According to Table 11, graduates with more than Rs.40 000 family income in sample of arts graduates are more likely to find their first job, when they were just passed out from the university than graduates with less than Rs.20 000 family income. Graduates who didn't do any extra - curricular activities in the university are more likely to find their first job between two to three years after graduation compared to graduates who were members of clubs. Compared to graduates who have not followed any professional courses, graduates who did professional courses are more likely to find their first job when they were just passed out. As in Table 11, graduates who did private sector jobs in considered sample are more likely to find their first job when they were just passed out comparing to the graduates who did jobs in government sector. 
Gunarathne \& Jayasinghe, Adv. J Social Sci.; Vol. 8, Issue 1, pp: 96-120, 2021

Table 11: $P$ values and Odds ratio for all the variables in Ordinal Logistic Regression model for Arts stream graduates

\begin{tabular}{|c|c|c|c|}
\hline Variables & $\mathrm{p}$ & \multicolumn{2}{|l|}{$\begin{array}{l}\text { Odds } \\
\text { Ratio }\end{array}$} \\
\hline Const (1) & 0.248 & & \\
\hline Const (2) & 0.001 & & $*$ \\
\hline Const (3) & 0.000 & & $*$ \\
\hline \multicolumn{4}{|l|}{ Gender [Male] } \\
\hline Female & 0.277 & 0.11 & \\
\hline \multicolumn{4}{|l|}{ Family Income [Less than Rs.20 000] } \\
\hline Rs.20000-Rs. 30000 & 0.156 & 2.96 & \\
\hline Rs.30000-Rs.40000 & 0.862 & 1.17 & \\
\hline More than Rs. 40000 & 0.015 & 49.16 & * \\
\hline \multicolumn{4}{|l|}{ Region of School [Urban] } \\
\hline Rural & 0.674 & 0.77 & \\
\hline \multicolumn{4}{|l|}{ Advanced Level English [“A”] } \\
\hline "B” passes & 0.814 & 0.71 & \\
\hline "C" passes & 0.300 & 0.25 & \\
\hline "S" passes & 0.859 & 0.77 & \\
\hline "F" passes & 0.874 & 0.81 & \\
\hline \multicolumn{4}{|l|}{ Extra-Curricular Activities [Clubs] } \\
\hline Organizing Events & 0.186 & 5.51 & \\
\hline Doing sports & 0.001 & 0.00 & * \\
\hline No & 0.001 & 0.04 & * \\
\hline \multicolumn{4}{|l|}{ Professional Courses [No] } \\
\hline Yes & 0.013 & 6.46 & * \\
\hline \multicolumn{4}{|l|}{ Job category [Government] } \\
\hline Private & 0.046 & 9.24 & * \\
\hline Self-employed & 0.469 & 1.83 & \\
\hline \multicolumn{4}{|l|}{ Usage of employment Services [No] } \\
\hline Yes & 0.253 & 0.48 & \\
\hline $\begin{array}{l}\text { Usage of Job search Strategies [Responding Job } \\
\text { advertisement] }\end{array}$ & & & \\
\hline $\begin{array}{l}\text { Asking relatives or } \\
\text { friends }\end{array}$ & 0.941 & 0.92 & \\
\hline Taking part in exams & 0.974 & 1.05 & \\
\hline Others & 0.205 & 0.24 & \\
\hline Participation for workshops [No] & & & \\
\hline Yes & 0.192 & 2.39 & \\
\hline
\end{tabular}

The reference level of each variable mentioned within squared brackets.

Signif. Codes: $0 * * * 0.001 * * 0.01 * 0.05 .0 .11$ 
Factors Affecting Unemployment Duration of the Science and Arts Stream University Graduates in Sri Lanka

\subsection{Identifying the set of variables that has similar (and contra) effect on time to first job between science and arts streams graduates}

Table 12: effect of each variable in unemployment duration models fitted for data related to science and arts stream graduates

\begin{tabular}{|c|c|c|}
\hline Variable & $\begin{array}{l}\text { Cox PH Model } \\
\text { (Science stream graduates) }\end{array}$ & $\begin{array}{l}\text { Ordinal Logistic Regression Model } \\
\text { (Arts stream graduates) }\end{array}$ \\
\hline Age & Insignificant & Data not available \\
\hline Gender & $\begin{array}{l}\text { Compared to Males } \\
\text { Females }\end{array}$ & Insignificant \\
\hline Stream & Insignificant & Not applicable \\
\hline Education Level & $\begin{array}{l}\text { Compared to } \\
\text { B.Sc. (General) } \\
\text { B.Sc. (Honours) } \\
\text { B.Sc. (Honours) in } \\
\text { Applied Sciences }\end{array}$ & Data not available \\
\hline Professional courses & Insignificant & $\begin{array}{l}\text { Compared to Not having followed any } \\
\text { professional courses } \\
\text { Having Followed any professional } \\
\text { Courses }\end{array}$ \\
\hline Workshop & Insignificant & Insignificant \\
\hline School Region & Insignificant & Insignificant \\
\hline Advanced Level English & $\begin{array}{l}\text { Compared to “A” passes } \\
\text { "B" passes } \\
\text { "C" passes } \\
\text { "F" Passes }\end{array}$ & Insignificant \\
\hline University Colours & Insignificant & Data not available \\
\hline Extra-curricular activities & Insignificant & $\begin{array}{l}\text { Compared to Member of a Club } \\
\text { Doing Sports } \\
\text { No }\end{array}$ \\
\hline Goal & Insignificant & Data not available \\
\hline Job Type & Insignificant & $\begin{array}{l}\text { Compared to Government } \\
\text { Private sector Jobs }\end{array}$ \\
\hline $\begin{array}{l}\text { Job search } \\
\text { strategy }\end{array}$ & Insignificant & Insignificant \\
\hline Family Income & Insignificant & $\begin{array}{l}\text { Compared to Less than Rs.20 } 000 \\
\text { More than Rs. } 40000\end{array}$ \\
\hline Employment services & Insignificant & Insignificant \\
\hline Job related to field of study & Insignificant & Data not available \\
\hline
\end{tabular}

Table 12 which presents a summary of effects of the considered variables on unemployment duration reveals that variables such as gender, education level, results obtain for Advanced Level English were the major factors that influenced unemployment duration of science stream graduates. The variables family income, extra-curricular activities, professional courses and job category were identified as having a significant effect on the unemployment duration of arts stream graduates. 


\section{Discussion}

This study focused on investigating unemployment duration of university graduates and determining the factors that influence the unemployment duration. Primary and secondary data were used in the process. In the secondary dataset response variable (time to obtain first job) was categorized as just passed out, within one year, between one to two years and between two to three years. Therefore, to find the factors that affect unemployment duration of arts stream graduates ordinal logistic regression, method was used. However, data related to science stream graduates could not be categorized using the same scale, because then all of them would belong to one category (within one year). By considering these limitations, result of the analysis related to secondary data that were used. Differing variables were used to get an idea about the factors that result in fluctuation of the time taken to find the first job and also to compare the "direction of the effect" on unemployment duration between the two sets of graduates.

According to descriptive analysis of data related to science stream graduates, $50 \%$ of the graduates in considered sample have found their first job within one month (30 days). However, half of female graduates in considered sample have found their first job within 60 days. As a percentage $50 \%$ of graduates who completed their degree in bio-Science stream found their first job by 60 days while half of graduates who did physical sciences found theirs within 30 days. Half of B.Sc. (Honours) in Applied Sciences degree holders in considered sample have found their first job within 30 days. As a percentage $50 \%$ of graduates who got "B" and "C" passes for Advanced Level English found their first job within 30 days. It was also observed that out of graduates who did sports as extra-curricular activities $50 \%$ have found their first job within 45 days. Half of graduates who did IT courses have found their first job within 30 days while $50 \%$ of graduates who did other courses such as HR, quantity survey, and such. have found their first job within 60 days. As a percentage 50\% of graduates with more than Rs.40 000 family income has found their first job within 30 days.

By descriptive analysis of arts stream graduates, it was observed that majority of graduates in the considered sample have found their first job within one year. Out of the graduates who found their first job between one to two years, majority were graduates with less than Rs.20 000 family income. Majority of graduates who have found their first job between two to three years after graduation have completed their secondary education at schools located in rural areas. Most graduates who obtained a "B" pass for Advanced Level English have found their first job within one year. Majority of graduates who found their first job just after passing out have organized different events such as Speech Master, aesthetic events, etc. as an extracurricular activity. Majority of graduates who found their first job right after graduation have found it by responding to job advertisement. Most graduates who have not participated in job-oriented workshops in considered sample have found their first job between two to three years.

\section{Conclusion}

This study focused on investigating unemployment duration of university graduates and determining factors that influence unemployment duration. The survival model was fitted to the data related to science stream graduates while an ordinal logistic regression model was fitted for arts stream graduates due to the nature of the data gathered. In conclusion, the findings of this study revealed that science stream female graduates tend to spend a longer time to obtain the first job compared to male graduates. Being a graduate holder of a specialized degree can increase the prospects of securing a job. However, GPA doesn't seem to have an impact on the unemployment duration. Science stream graduates with "B", "C" and "F" passes for Advanced Level English tend to consume a shorter time to obtain first job than graduates with "A" pass. As this was an out of ordinary observation, by a deeper analysis revealed some interesting characteristics of this group of students; majority of graduates with "B", "C" and "F" passes for Advanced Level English have completed B.Sc. (General) degree in Physical Science stream and most of graduates with "C" and "F" passes for Advanced Level English have not considered about the working environment when taking up their first job. Arts stream graduates with more than Rs.40,000 family income in considered sample are 
more likely to find their first job, when they were just passed out from the university than graduates with less than Rs.20,000 family income. Arts stream graduates who didn't do any extra-curricular activities in the university are more likely to find their first job within three years after graduation compared to graduates who were members of university clubs. Furthermore, Arts stream graduates who did professional courses are more likely to find their first job when they were just passed out compared to graduates who have not followed any professional courses.

\section{Declarations}

\subsection{Study Limitations}

The response rate was affected due to invalid contact details in the database. Another limitation of the research was the use of secondary data to get information related to arts stream graduates, and consequently the lack of information related to factors such as degree type (education level) of graduates which became significant for unemployment duration of a science stream graduate.

Furthermore, in secondary data set response variable (time to obtain first job) has been categorized as just passes out, within one year, between one to two years and between two to three years. Therefore, it was analyzed using ordinal logistic regression. However, data related to science graduates could not be categorized using the same categories, because all of them would then belong to one category (within one year). By considering these limitations, secondary data were used just to get an idea about similarities / differences of the factors that affect the time taken to get the first job of graduates of the two streams. It would be important to further investigate the association of survival with other factors such as past working experiences and also consider the interactions among covariates and conduct similar studies for other streams of study such as engineering and management sciences.

\subsection{Acknowledgements}

We would like to specially thank all the participants of this study and the staff of the USJ Academic, Student Affairs Branch for providing details of the students. The authors would also like to acknowledge the reviewers and the editorial board for their valuable feedback and suggestions which improved the readability and the presentation of the paper.

\subsection{Informed Consent}

A written informed consent was taken from each participant by explaining the objectives of the study and ensuring the privacy. Access to the collected data was limited only to the authors for concealment.

\subsection{Competing Interests}

The authors declared that they have no conflict of interest.

\section{How to Cite this Article:}

Gunarathne, L., \& Jayasinghe, C. L. (2021). Factors Affecting Unemployment Duration of the Science and Arts Stream University Graduates in Sri Lanka. Advanced Journal of Social Science, 8(1), 96-120. https://doi.org/10.21467/ajss.8.1.96-120

\section{References}

Altay, M. (2020). The implications of EMI Education for Graduates' Employment Conditions. Kocaeli Üniversitesi Sosyal Bilimler Dergisi, 1-12. https://doi.org/10.35343/kosbed.810502

Ariyawansa, R.G., 2008. Employability of graduates of Sri Lankan universities. Sri Lankan Journal of Human Resource Management, 1(2). doi: http://dx.doi.org/10.4038/sljhrm.v2i1.5107

Babucea, A.G. and Danacica, D.E., 2007. Using Kaplan-Meier curves for preliminary evaluation the duration of unemployment spells. https://mpra.ub.uni-muenchen.de/7854/

Boudarbat, B., 2008. Job-search strategies and the unemployment of university graduates in Morocco. International Research Journal of Finance and Economics, 14, pp.15-33.

Ciuca, V.A.S.I.L.I.C.A. and Matei, M.O.N.I.C.A., 2010, October. Survival analysis for the unemployment duration. In Proceedings of the 5th WSEAS International Conference on Economy and Management Transformation (Vol. 1, pp. 354-359). 
Gunarathne \& Jayasinghe, Adv. J Social Sci.; Vol. 8, Issue 1, pp: 96-120, 2021

Cockshott, C. J., Kiemle, G., Byrne, P., \& Gabbay, M. B. (2021). A Fall from Grace: An Interpretative Phenomenological Analysis of Unemployment in UK University Graduates with Common Mental Health Issues. Open Journal of Social Sciences, 09(01), 291313. https://doi.org/10.4236/jss.2021.91021

Dănăcică, D. and Babucea, A.G., 2007. The role of education for the duration of unemployment in Gorj Country. Studia Universitatis Babes Bolyai-Oeconomica, 1, pp.67-82. doi: https://doi.org/10.1016/S2212-5671(14)00574-7

Dickens, W.T. and Lang, K., 1995. An analysis of the nature of unemployment in Sri Lanka. The Journal of Development Studies, 31(4), pp.620-636. doi: https://doi.org/10.1080/00220389508422381

Dissanayake, E.L. and Benfratello, L., 2010. Determinants of Unemployment among Sri Lankan University Graduates. International Training institute of the ILO Turin. http://maled-dl.itcilo.org/study-paper-area-1/Thesis_Dissanayake_A.Y.20102011.pdf

Ekanayaka, E. M. M. S., \& Gamage, P. (2019). Factors Influencing Job Seeker's Intention to Use E-Recruitment: L Evidence from a State University in Sri Lanka. International Journal of Managerial Studies and Research, 7(8), 50-62. https://doi.org/10.20431/23490349.0708001

Foley, M.C., 1997. Determinants of unemployment duration in Russia. doi: 10.22004/ag.econ.28427

Gabriel, D., Brigitte, S.C. and Elisabeta, J., 2017. Estimation of Unemployment Duration in Botoşani County Using Survival Analysis. Ovidius University Annals, Series Economic. http://stec.univ-ovidius.ro/html/anale/RO/2017/Section-III/7.pdf Sciences, 17(1). v

Getie Ayaneh, M., Dessie, A. A., \& Ayele, A. W. (2020). Survival Models for the Analysis of Waiting Time to First Employment of New Graduates: A Case of 2018 Debre Markos University Graduates, Northwest Ethiopia. Education Research International, 2020, 1-10. https://doi.org/10.1155/2020/8877504

Jayasingha, D., \& Suraweera, S. (2020). An Analysis of the Factors Affecting the Graduates' Employability in Case of Rajarata University of Sri Lanka. IRE Journals, 3(12), 1-15.

Jayathilake, H. D. (2020). The Impact of Unemployed Youth on National Development in Sri Lanka. Journal of Emerging Issues in Economics, Finance and Banking (JEIEFB).

Khezri, N., Rezaei, M., \& Aram, M. (2020). Injustice, Uselessness, and Illness: A Qualitative Study of Unemployed Graduates’ Lives in Iran. Education and Urban Society, 52(1), 70-91. https://doi.org/10.1177/0013124519856678

Khouli, M. E. (2021). Examining the Trends of Educational Variables in the Past Affecting Egypt's Ability to Becoming Future-Proof in Facing Unemployment. Athens Journal of Mediterranean Studies, 7(2), 143-154. doi:10.30958/ajms.7-2-4

Lam, D., Leibbrandt, M. and Mlatsheni, C., 2007. Dynamics of labor market entry and youth unemployment in South Africa: evidence from the cape area panel study. https://deepblue.lib.umich.edu/bitstream/handle/2027.42/55748/IPC-working-paper-034-Lam.pdf

Thomas, L. and Reyes, E.M., 2014. Tutorial: survival estimation for Cox regression models with time-varying coefficients using SAS and R. J Stat Softw, 61(c1), pp.1-23. https://www.jstatsoft.org/article/view/v061c01/v61c01.pdf

Unemployment Rate Definition. (2020, July 28). Investopedia. https://www.investopedia.com/terms/u/unemploymentrate.asp

Weerasiri, A. R. P., \& Samaraweera, G. R. S. R. C. (2021). Factors influencing Youth Unemployment in Sri Lanka. ASIAN JOURNAL OF MANAGEMENT STUDIES, 1-24. http://repo.lib.sab.ac.lk:8080/xmlui/handle/123456789/1650

Wimalarathna, B. M. R. M., Kumara, P. H. T., \& Niroshini, S. (2020). Causes of Unemployment among the Educated Youth in Sri Lanka. 1. http://www.erepo.lib.uwu.ac.lk/bitstream/handle/123456789/5674/proceeding_oct_08-147.pdf

Publish your research article in AIJR journals-

$\checkmark \quad$ Online Submission and Tracking

$\checkmark$ Peer-Reviewed

$\checkmark$ Rapid decision

$\checkmark \quad$ Immediate Publication after acceptance

$\checkmark$ Articles freely available online

$\checkmark \quad$ Retain full copyright of your article.

Submit your article at journals.aijr.org
Publish your books with AIJR publisher-

$\checkmark \quad$ Publish with ISBN and DOI.

$\checkmark$ Publish Thesis/Dissertation as Monograph.

$\checkmark \quad$ Publish Book Monograph.

$\checkmark \quad$ Publish Edited Volume/ Book.

$\checkmark$ Publish Conference Proceedings

$\checkmark \quad$ Retain full copyright of your books.

Submit your manuscript at books.aijr.org 